American Journal of Agricultural and Biological Sciences 3 (3): 559-565, 2008

ISSN 1557-4989

(C) 2008 Science Publications

\title{
Evaluation of Hydroponic Production of Vegetables and Ornamental Pot-Plants in a Heated Greenhouse in Western Macedonia, Greece
}

\author{
${ }^{1}$ Ioannis I. Papadopoulos, ${ }^{1}$ Fotis Chatzitheodoridis, ${ }^{2}$ Christos Papadopoulos, \\ ${ }^{2}$ Vasilios Tarelidis and ${ }^{1}$ Christina Gianneli \\ ${ }^{1}$ Technological Education Institute of W. Macedonia, 53100 Florina, Greece \\ ${ }^{2}$ Public Power Corporation S.A., Ptolemaida Greece
}

\begin{abstract}
In this research an evaluation-in terms of investments-of hydroponics greenhouses is carried out, as well as the possibility of the development of greenhouse crops cultivations, such as vegetables and flowers, in them is explored in Western Macedonia. The survey was realized between the years 2002-2006, in a model greenhouse, which was installed by the Public Power Corporation S.A., in soils that are to be restored after the excavation of lignite. In this research, a comparative analysis of different hydroponics systems was carried out, in relation to the initial investment by the Net Present Value and the inexpensiveness of the cultivations. The findings indicate that only with subsidy is such an investment advantageous.
\end{abstract}

Key words: Greenhouses, hydroponics systems, investment evaluation, net present value

\section{INTRODUCTION}

The greenhouse businesses are considered as the more intensive businesses in the Greek agriculture and substantially contribute both to the configuration of the agricultural income and to the national income. The branch of agricultural businesses presents immense possibilities of development within the frame of the expansion of the European Market and the extension of national trade. In the recent years in Greece, the sector of greenhouse cultivations has been facing profound problems $^{[12]}$.

The cultivation of greenhouse crops and the achievement of high yields and good quality are possible with hydroponics due to the precise control of nutrition and all the growing conditions ${ }^{[2]}$. In recent years, a shift from open to closed hydroponics systems has been observed in the greenhouse industry ${ }^{[8]}$. In hydroponics systems with continuous nutrient solution flow, such as NFT, the reuse of nutrient solution has primarily an environmental impact as reduces leaching of fertilizers and prevents ground water pollution as well as minimizes irrigation and fertilization labour input $^{[1]}$. NFT enables a longer cropping period and the possibility of adopting high plant densities to increase the output per cropped area ${ }^{[9,26]}$. Cultivation tests involving different hydroponics systems and different substrates have been made to determine the most appropriate for each crop in respect of product quality and crop yield ${ }^{[26]}$.

Hydroponics have reported been used for vegetable production in non-arable or contaminated regions ${ }^{[6,13]}$ since the world war. The expansion of hydroponics nowadays all over the world may be attributed to their ability to be independent of all the soil related problems like the decline of soil structure and fertility or high salinity ${ }^{[25]}$

Climatic conditions are one of the most important factors to determine the economy of glasshouse cultivation $^{[4]}$. The high cost of heating greenhouses due to escalating fuel costs has created a crisis situation in the greenhouse industry ${ }^{[32]}$. As a result, interest in methods of energy conservation, in alternate less costly sources of energy and in plants which grow satisfactorily in cooler environments has become intens $^{[33,30]}$. Many applications of non conventional energy sources, such as industrial thermal effluents have been reported ${ }^{[15]}$. Heating systems utilizing exhaust gases from a coal fired unit have been constructed in Canada and USA ${ }^{[19,18]}$. Waste heat, especially in the form of heated water, has been used effectively for greenhouse heating in many north European countries ${ }^{[31,27,11,23,3]}$. The simultaneous production of heat and power is another important option for economic greenhouse crop production ${ }^{[16]}$. Economical heat supply for greenhouses on basis of

Corresponding Author: Fotis Chatzitheodoridis, Technological Education Institution (T.E.I) of Western Macedonia, Terma Kontopoulou Str., -53100 Florina, Greece Tel: +30-23850-54654 
district heating from a large combined power heating station has been reported in the Netherlands ${ }^{[22,17]}$. West Macedonia has a dry, cold continental climate and there are no commercial greenhouse crops because of high cost of heating. The brown coal mining centre of West Macedonia, composed of 5 main open-cast mines, covers an area of $160.000 .000 \mathrm{~m}^{2}$ and produces the $60 \%$ of the electrical power production in Greece. The mined brown coal is used by the Public Power Corporation S.A. (P.P.C.), while the infertile material is transported and deposed in already closed mines or other pre-selected areas. These activities have changed the landscape and morphology of thousands acres of land mainly used for agriculture and have caused a reduction in agricultural extents. The P.P.C, in terms of the rehabilitation of regions stricken by brown coal mining has initiated a research programme in collaboration with the Western Macedonia Technological Educational Institute on the agricultural utilization of non fertile deposits. A greenhouse has installed with soil less culture systems and the possibility of applying district heating, based on the combined production of electrical and thermal power from the Public Power Production Stations, aiming mainly at the study of the hydroponics production cost of greenhouse crop production.

In this research, certain tomato cultivations, lettuces and flowering pot plants have been studied in cultivating combinations with the use of two hydroponics systems (NFT and substratum of inert materials). In particular, we looked into the output, the income and the cost of those cultivations aiming to the assessment and evaluation of the result of the hydroponics greenhouse cultivations in an area with particularly low temperatures during the winter, considering the limited cost of heating of the greenhouses, as well. At the same time, a trial in a broader sense has been made, regarding these greenhouse businesses in Western Macedonia, seen as investments which involve great uncertainty. The producer-investor in the primary sector is in need of investments which improve their financial status and among the plethora of investing options they should choose and materialise the ones which shall effect the best financial result possible ${ }^{[21]}$.

\section{MATERIALS AND METHODS}

In September 2002-2006, in the greenhouse of P.P.C. S.A the survey was realised, where a programme of interchange of cold-demanding cultivations was put into practice during the winter and warm-demanding cultivations during the summer.
The greenhouse of Public Power Corporation S.A has an infrastructure of hydroponics cultivations where some alterations were made so as to support plants of different type of growth and size. It concerns a double modified arched greenhouse E-W orientated, with a frame of galvanised-in-heat pipes. It has a double glazed roof window in each arch in the shape of a butterfly and also a window in the lee side. The total area is $1000 \mathrm{~m}^{2}(50 \times 20 \mathrm{~m})$.

The installation of the hydroponics systems concerned two different systems of hydroponics cultivation, one system in each arch of the greenhouse. The first system, NFT, concerned an experimental cultivation circle of lettuce-tomato, in the croppingcultivation periods in winter and autumn from 20022006. The second system concerned cultivation in substrata of inert materials (peat-pearlite-pumicegrodan) and an experimental cultivation circle of flowering pot plants and tomato was realised, in the cultivation periods in winter and autumn from 20022006.

The primary data of the project was drawn by the researchers who participated in the survey during the period and the progress of the cultivating procedures. The main body of the primary data concerns the financial data and data relative to the cultivations themselves, the hydroponics systems which were used, their output and their reciprocation in general to the greenhouse environment.

Particularly, the analysis methods which were used were the following:

- The standard technical and financial analysis for the purpose of the exploration of the inexpensiveness of the exploitations. There has been used the accounting method and the correlation of the financial results, in order to define the inexpensiveness of the exploitations, the drawing of the financial results and the relation to each other ${ }^{[14]}$

- The method of Net Present Value for the assessment of the investments. The Net Present Value comprises the algebraic difference between the influx and outflow of the capital expressed in present values ${ }^{[28]}$. We use as rate of interest the cost of capital, which comprises the minimum acceptable percentage of return, in order to assess the present value. The investment work or the business which has positive present value will increase the value of the investment according to this amount and therefore should be acceptable ${ }^{[20]}$. In cases of mutually excluded investment plans, the one with the highest Net Present Value is chosen 
The mathematical expression of the criterion of the Net Present Value is ${ }^{[10]}$ :

$$
\text { N.P.V. }=\mathrm{I}_{0}-\Sigma_{(\tau=1, \mathrm{~T})} \mathrm{CFt} /(1+\mathrm{R})^{\mathrm{t}}
$$

Where: $I_{0}$ is the initial cost of investment, $T$ the term of life of the investment, $\mathrm{CF}_{\mathrm{t}}$ the cash flow in time and $\mathrm{R}$ the discount rate of interest.

The assessment of the investments, with the criterion of the Net Present Value, was realized for greenhouses of one, ten and twenty square meters with hydroponics systems (NFT and substratum of inert materials) and concerned the interchange of certain cultivations. The discount rate of interest, which was used in the particular analysis, comprises the average long-term borrowing rate of interest in agriculture, augmented according to $1 \%$ as error margin and equals to 6 and $5 \%^{[5]}$. The data which were used and concerned the output, the prices, the production expenses and the investment costs, were evident from the accounting observation of the pilot cultivations, from other representative greenhouse exploitations and from the Ministry of Agriculture. The construction and equipment costs were made evident from data of relative companies.

In the analysis, the criterion of the Net Present Value was used in a modified form, so as to include the uncertainty involved in the perennial financial profitability of the investment. The modification of the criterion was based on the use of secondary influx prices which are simulated in the form of distribution ${ }^{[24]}$ and not on the use of current influx prices. This method requires the creation of timelines, in order to predict the profitability of the opportunity of investment in time. The succession of the results is simulated with many repetitions and the constants of the random advancement are defined by the facts of simulation. This method depends on one and only hypothesis, the same that was presented by Cox et al. ${ }^{[7]}$, which is a distinct procedure of approach with geometrical (Brownian motion) advancement. In the present paper timelines of output and price, from secondary bibliographical data which concern instances of greenhouses with corresponding size, similar cultivations and in approximate area of installation ${ }^{[21]}$, are used. For the simulation the program Best Fit for windows was used, while at the same time, an adjustment to the particular data of the present paper has been made.

\section{RESULTS AND DISCUSSION}

According to the survey, in the area of the depositions where the prototype greenhouse of P.P.C.
S.A is installed, the value of the land comes to $800 €$ per acre, while the rent of an acre comes to $40 €$ yearly. The cost of the construction of an acre greenhouse, in the area of research, comes to $18000 €$ and the commission and installation cost of the hydroponics system comes to $3000 €$.

During the hydroponics cultivation with the system NFT, five types of lettuce and two types of tomato were tried (Table 1). For the cultivations seedlings were used and they were produced in the seed-plot of the greenhouse. A growth and progress control of the cultivations was conducted by weekly and monthly analyses of specimens of nutritious solutions.

In the case of the cultivation of lettuces, the plants were grown in perfect climatic conditions and they did not undergo serious entomologic or mycetologic damages, throughout all the periods of cultivation. In the case of the tomato, the density of planting was 2200 plants/square meter, their growth in NFT was regular

Table 1: Yields and gross incomes of varieties of lettuce, tomato and flower pot plants in a one acre greenhouse, with hydroponics systems NFT and inert substrata (average prices 2002-2006)

NFT SYSTEM Average INERT SUBSTRATE

SYSTEM

yield $\mathrm{Kg}$ /acre Producer Average yield Piece or Kg/acre

average price $€ / \mathrm{Kg} \quad$ Producer average price $€ /$ piece

Gross Income $€ /$ acre $\quad$ or Kg Gross Income $€ /$ acre

LETTUCE POT-PLANTS

November - January (3 months) January - April (4 months)

Attraction Zonal pelargonium

$3900 \quad 9000$

1.5

$5850 \quad 11700$

Great lakes Ivy-leaved pelargonium

$2800 \quad 90000$

$1.9+1.5$

$5320 \quad 13500$

Simson Regal pelargonium

$4150 \quad 9000$

$1.5-1.6$

$6225 \quad 14400$

Lolo-Rosa Fuchsias

$2800 \quad 9000$

$1.7 \quad 1.6$

$4760 \quad 14400$

Endive Cape marigolds

$3500 \quad 9000$

$1.0-1.3$

$3500 \quad 11700$

TOMATO TOMATO

February - October (9 months) June - December ( 8 months)

Belladonna Belladonna

$14730 \quad 12446$

$0.65 \quad 0.7$

$9574 \quad 8712$

Ardilas

13852

0.65

9004 
and they did not show any signs of lack of nutrients in any stage. There were loses of plants and sprout snaps at regular levels.

As seen in Table 1, the loose-leaf type lettuce Attraction and Simson and the tomatoes type Belladonna had higher average yield in all the periods of cultivation compared to the other types, a fact which determined the higher gross income per acre.

During the hydroponics cultivation of the flower pot plants and the tomato with the system of inert substrata, five different ornamental species and one type of tomato were tested (Table 1). For the cultivation of the tomato, seedlings which were produced in the seed-plot of the greenhouse were used, while for the flowering pot plants, a supply of rooted cuttings was carried out. The irrigation and fertilization of the plants was done through a system of dripping and during the growth of the plants, a program of plant protection with precautious spaying was implemented. During the cultivation no serious problem was dealt with and the losses of the plants were limited to the minimum (15 plants out of 2500).

In Table 1, the average yields in various kinds of plants of the flowering pot, in all the cultivating periods, was the same (9000 pieces per acre). The fuchsias and the regal pelargonium had higher average price in all the cultivating periods than the rest kinds, a fact which determined the highest gross income per acre.

The demands, of the greenhouse cultivations of lettuce, tomato and flower pot plants, in human labour come to 120, 630 and 200 hours per year respectively, per acre (Table 2). Based on the hydroponics system and the determined interchange of cultivations, the average annual required labour in the cultivations with NFT system (interchange of lettuce-tomato) came to 750 hours per acre and with the system of inert substrata (interchange of flower pot plants-tomato) came to 840 hours per acre per year, respectively.

From the analysis of the structure of the expenses per factors of production (Table 2), we can see that the greenhouse cultivation of lettuce is intensified in relation to production, mainly concerning the labour $(19,5 \%)$ and the capital $(79,6 \%)$, especially in the form of variable and fixed expenses (54\% and $18 \%$ respectively). The greenhouse cultivation of the tomato is intensified mainly concerning the labour (48\% and $49,6 \%$ for the two hydroponics systems), in the form of fix expenses $(12,2 \%$ and $13,5 \%)$. The cultivation of flowering pot plants is intensified mainly concerning the capital, especially in the form of variable expenses and plant capital (54, 3\% and 28, 7\% respectively). The incredibly low contribution of the land is remarkable in the configuration of the total capital in all cultivations.

Table 2: Expenses per production factors of lettuce, tomato and flower pot plants in a one acre greenhouse, with hydroponics systems NFT and inert substrata (average prices 2002-2006)

\begin{tabular}{|c|c|c|c|c|}
\hline NFT SYSTEM & LETTUCE & & TOMATO & \\
\hline Categories of expenses & $€ /$ acre & $\%$ & $€ /$ acre & $\%$ \\
\hline \multicolumn{5}{|l|}{ Expenses/Factors of production } \\
\hline Land (rent: 1acre) & 40 & 0.9 & 40 & 0.4 \\
\hline Labour cost (total labour $\mathrm{h} * € / \mathrm{h}$ ) & $840(120 * 7 €)$ & 19.5 & $4410(630 * 7 €)$ & 48.0 \\
\hline \multicolumn{5}{|l|}{ Capital } \\
\hline Variable expenses & 2335 & 54.3 & 2568 & 28.1 \\
\hline Annual expenses of plant capital & 140 & 3.2 & 480 & 5.2 \\
\hline Annual expenses of fixed capital & 790 & 18.3 & 1237 & 13.5 \\
\hline Taxes, various expenses, etc. & 163 & 3.8 & 437 & 4.8 \\
\hline Total $(1-3)$ & 4308 & 100 & 9172 & 100 \\
\hline Production cost ( $€ /$ acre $)$ & 4308 & - & 9172 & - \\
\hline Yield (kg/acre) & 3900 & - & 14730 & - \\
\hline Cost $(€ / \mathrm{kg})$ & 1.1 & - & 0.62 & - \\
\hline INERT SUBSTRATE SYSTEM & FLOWER POT-PLANTS & TOMATO & & \\
\hline Categories of Expenses & $€ /$ acre & $\%$ & $€ /$ acre & $\%$ \\
\hline \multicolumn{5}{|l|}{ Expenses/Factors of production } \\
\hline Land (rent: 1acre) & 40 & 0.3 & 40 & 0.5 \\
\hline \multirow{2}{*}{\multicolumn{5}{|c|}{ Capital }} \\
\hline & & & & \\
\hline Variable expenses & 8515 & 54.3 & 2504 & 27.7 \\
\hline Annual expenses of plant capital & 4500 & 28.7 & 480 & 5.3 \\
\hline Annual expenses of fixed capital & 480 & 3.0 & 1099 & 12.2 \\
\hline Taxes, various expenses, etc. & 750 & 4.8 & 432 & 4.7 \\
\hline Total $(1-3)$ & 15685 & 100 & 9035 & 100 \\
\hline Production cost (€/acre) & 15685 & - & 9035 & - \\
\hline Yield (Piece or kg/acre) & 9000 & - & 12446 & - \\
\hline Cost $(€ /$ piece or kg $)$ & 1.75 & - & 0.72 & - \\
\hline
\end{tabular}


Am. J. Agri. \& Biol. Sci., 3 (3): 559-565, 2008

Table 3: Results of the evaluation of an investment on a hydroponics greenhouse, sized 1 acre, with a NFT system and a system of inert substrate in Western Macedonia (2006-2007)

\begin{tabular}{|c|c|c|c|c|c|c|c|}
\hline $\begin{array}{l}\text { Net } \\
\text { present } \\
\text { value }\end{array}$ & $\begin{array}{l}\text { Investment } \\
\text { of } 1 \text { acre } \\
\text { without } \\
\text { subsidy }\end{array}$ & $\begin{array}{l}\text { Investment } \\
\text { of } 1 \text { acre } \\
\text { with } \\
\text { subsidy }\end{array}$ & $\begin{array}{l}\text { Investment } \\
\text { of } 10 \text { acres } \\
\text { without } \\
\text { subsidy }\end{array}$ & $\begin{array}{l}\text { Investment } \\
\text { of } 10 \text { acres } \\
\text { with } \\
\text { subsidy }\end{array}$ & $\begin{array}{l}\text { Break even } \\
\text { investment } \\
\text { without } \\
\text { subsidy (acres) }\end{array}$ & $\begin{array}{l}\text { Break even } \\
\text { of investment } \\
\text { with subsidy } \\
\text { (acres) }\end{array}$ & $\begin{array}{l}\text { Break even of } \\
\text { investment with } \\
\text { subsidy } \\
\text { (years/months) }\end{array}$ \\
\hline $\begin{array}{l}\text { Greenhouse with } \\
\text { NFT system }\end{array}$ & -23.277 & -11.895 & -950 & 8.113 & 11.2 & 5.3 & $6(8)$ \\
\hline $\begin{array}{l}\text { Greenhouse with inert } \\
\text { substrate system }\end{array}$ & -34.517 & -23.873 & -5.567 & 3.496 & 23.8 & 8.9 & $8(11)$ \\
\hline
\end{tabular}

The analysis in the level of the hydroponics systems and the interchange of cultivations which were studied, showed that the average annual total production expenses for the NFT system (interchange of lettucetomato) came to $11806 €$ and for the inert substrate system (interchange of flower pot plants-tomato) to $23258 €$. In the NFT system, the structure of the production expenses is intensified mainly concerning labour and variable expenses, while in the system of inert substrata the structure of the production costs is intensified mainly concerning labour, variable expenses and plant capital.

In the case of the variable expenses and the two hydroponics systems, the cost of heating fuel of the greenhouse is dominant (average expense $4038 €$ per year in the system of NFT and $8500 €$ in the system of inert substrata which correspond to a percentage of $34 \%$ and $36,5 \%$ of the total yearly production expenses). Moreover, the contribution of the plant capital is particularly high in average total production expenses, in the case of the inert substrata $(22 \%)$, a fact which is mainly due to the cultivation of the flower pot plants and the supply of multiplying material from abroad.

The average yearly gross income for the NFT system (interchange of lettuce-tomato) came to $15424 €$ and for the system of inert substrata (interchange of flower pot plants -tomato) came to $23112 €$. On average, the NFT system produced profit ( $3618 €$ per acre), while the system of inert substrata produced marginal damage (- $146 €$ per acre).

From the assessment of the two hydroponics greenhouses as investments, the fact that their installation in the area of Western Macedonia came up as non-advantageous (Table 3), since the Net Present Value is negative, both in the case of NFT and in the case of the inert substrata. The analysis showed negative results, though greatly improved, in the case where the greenhouse business is subsidized by $50 \%$ of the total cost of the investment. However, the analysis was realized just for one acre of the greenhouse without assessing the possible economization by the greater size. According to the bibliography ${ }^{[29]}$, a size economization is accomplished by $10 \%$ in the construction cost and 3\% in functional cost for each additional acre, without affecting the relative returns. Thus, the repetition of the analysis for greenhouses of the two hydroponics systems and with similar cultivations and their interchanges, of a 10 acres size, in both a subsidized investment and non-subsidized investment respectively, shows the results in Table 3.

According to their break even, the investments without subsidy present profit only when their size is larger than 11, 2 square meters in the case of the NFT system and a size larger than 23, 8 square meters in the case of the system of the inert substrata. Based on these results, if the investment is not included in a program of subsidy, it cannot counterbalance the cost from the influxes of the investment, a fact which leads to the non-acceptance of the investment program.

The support of relative investments with a percentage of $50 \%$ of the total cost - a fact which is usual and almost universal due to the different agricultural and regional policies in European Union substantially decreases the break even of the two alternative investments and leads to the undertaking of the investment risk. The greenhouse NFT, with subsidy and without economizations of size, shall be profitable in 6 years and 11 months. Respectively, in the case of economizations of size, these time periods are limited even more and the efficiencies of the investment are substantially increased (Table 3).

\section{CONCLUSIONS}

The use of the modified criterion of the Net Present Value, so that it takes into consideration the risk and the uncertainty of the assessment of the investments, is a more powerful tool which has the potential to deal with the weaknesses of the standard assessment criteria in a better way and to meet the present situations. According to the modified criterion of the Net Present Value, the investment in the area of Western Macedonia on a modern hydroponics greenhouse, either of an NFT system or a system of the inert substrata, without subsidy, is not feasible. On the contrary, the investment with a cost subsidy for $50 \%$ proves to be 
advantageous. In order that the investment of a modern greenhouse in Western Macedonia be considered profitable, its accession is necessary either to a subsidy program or the investment be of a great scale.

If the gross income which results from the cultivation of lettuce, tomato and flower pot plants, is not high then it seems that the hydroponics cultivations both in the NFT system and the system of inert substrata, constitute interesting choices for the farmer of interchange of cultivations, taking into consideration the duration of the winter in the wider area of Western Macedonia.

From the analysis of the inexpensiveness, it is evident that these cultivations, both on their own and in the context of interchange as a whole and on a yearly basis, are intensified concerning the labour and the capital, a fact which lets limited margin for further intensifying of the cultivations. The reduction of the production cost is mainly in relation to the size. The NFT system with interchange of lettuce-tomato presents profit on average, while the system of inert substrata with interchange of flower pot plants- tomato, presents marginal damage, which is mainly due to the high variable expenses and the high cost of the plant capital.

Dominant is revealed the high expense of heating the greenhouses, in the configuration of the average total production expense of all the cultivations and systems, a fact which allows, in case of potential reduction in its cost, the improvement of the financial results. In this direction, the available cheap energy sources (lignite, biomass, geothermical sources of low enthalpy, tele-heating network) in Western Macedonia can contribute, but also the potential establishment by the supplier of energy and cheaper rates in the cases of greenhouse businesses, can contribute to the same extent.

\section{REFERENCES}

1. Adams, P., 1991. Hydroponic systems for winter vegetables. Acta Hort., (ISHS), 287: 181-190.

2. Adams, P., 2002. Nutrition Control in Hydroponics. In: Hydroponic production of Vegetables and ornamentals. Savvas, D. and H. Passam (Eds). Embryo Publications, Athens Greece.

3. Bredenbeck, H., 1992. The use of waste heat from a power plant for greenhouse heating in commercial application in Germany. Acta Hort., (ISHS) 312:29-36

4. Ciechomski, W., 1978. Influence of climatic factors upon costs of fuel and location of glasshouses. Acta Hort., (ISHS) 76:87-90
5. Committee of European Communities, (2000). Guide for the Cost - Benefit Analysis of large scale projects, D.G. Regional Policy, pp: 28.

6. Cooper, A., 1979. The ABC of NFT. Grower Books, London.

7. Cox, J.C., S.A., Ross and M., Rubinstein, 1979. Option pricing: A simplified approach. J. Financial Econ., 7: 229-263.

8. De Kreij, C., W.T. Runia and A. van der Burg, 2001. Exudates, their decomposition, production of tomato and bioassays from open and closed rockwool system. International Symposium on Growing Media and Hydroponics. Aluarpa, Sweden, 8-14 September 2001 Abstracts, C12.

9. Graves, C.J., 1983. The nutrient film technique. Hort. Rev., 5: 1-44.

10. Hartwich, J.M. and N.D. Olewiler, 1998. The Economics of Natural Resource Use. 2nd Edn. Addison Wesley Educational Publishers, USA.

11. Hietala, J.S. and G.C. Ashley, 1984. History and status of selected waste heat greenhouse projects. Acta Hort., (ISHS) 148: 233-238.

12. Institute of Natural Resource Management and Development, 1994. Investigation Study for the Enterprising Modernisation of Greenhouses in Greece. ETBA, Athens (in Greek).

13. Jones, J., 1982. Hydroponics: Its history and use in plant nutrition studies. J. Plant Nutr., 5: 1003-1030.

14. Kitsopanidis, G., 1986. Economic Principals of Agricultural Production. Ziti Publications, Thessaloniki (in Greek).

15. Knies, P., 1989. Greenhouse heating with waste heat as base load. Acta Hort., (ISHS) 245: 190-198.

16. Klaauw, D., 1992. Masterplan for combined heat and power in greenhouse horticulture in the Netherlands. Acta Hort., (ISHS) 312: 45-54.

17. Maare, O., 1992. Economical heat supply of greenhouses experiences from Denmark. Acta Hort., (ISHS) 312: 37-44.

18. Maginnes, E.A., M.O. Haukeness, G.H. Green and K.E. Miller, 1978. Utilizing turbine exhaust gases for heating and carbon dioxide enrichment of greenhouses. Acta Hort., (ISHS) 76: 243-246.

19. Maginnes, E.A. and G.H. Green, 1978. Greenhouse heating with exhaust gases. Acta Hort., (ISHS) 87: 343-350.

20. Mergos, G., 2002. Social Evaluation of Investments. Department of Economics, Publications of National University of Athens, Athens (in Greek).

21. Michailidis, A. and K. Mattas, 2007. Using real options theory to dam investment analysis: An application of binomial option pricing model. Water Resour. Manage., 21: 1717-1733. 
22. Mulder, W.P. and B.J. Heijna, 1981. The use in greenhouses of hot water resulting from electric power generation. Acta Hort., (ISHS) 115: 617-626

23. Parrini, F., D. Casarotti and S. Pulvirenti, 1990. Thermoelectric plants waste heat utilization for protected ornamental cultivations. Acta Hort., (ISHS) 263: 239-252.

24. Purvis, A., W.G., Boggess, C.B., Moss and J. Holt, 1995. Technology adoption decisions under irreversibility and uncertainty: An ex ante approach. Am. J. Agric. Econ., pp: 541-551.

25. Raviv, M., R. Wallach, A. Silber and A. Bar Tal, 2002. Substrates and their Analysis. In: Hydroponic Production of Vegetables and Ornamentals, Savvas, D. and H. Passam (Eds). Embryo Publications, Athens Greece.

26. Sen, F. and A. Sevgican, 1999. Effect of water and substrate culture on fruit quality of tomatoes grown in greenhouses. Acta Hort., 486: 349-352.

27. Sonneveld, A., 1984. Utilization of extract and reject heat for greenhouse heating in the Netherlands. Acta Hort., (ISHS) 148: 219-226.
28. Tsaklaganos, A., 1980. Investments Evaluation I. Publications Kiriakidi brothers, Thessaloniki.

29. Tzouramani, E., 1999. Decisions on Investments in Intensive Greenhouse Cultures and in Treaties of Uncertainty. PHD Thesis, Aristotles University of Thessaloniki, Thessaloniki (in Greek).

30. Van de Braak, N.J., 1989. New methods of greenhouse heating. Acta Hort., (ISHS) 245: 149-157.

31. Van der Sluis, B.J. and K.R. Nawrocki, 1992. Coverage of reject heat in the Dutch greenhouse industry. Acta Hort., (ISHS) 312: 109-114.

32. Van der Velden, N.J.A. and A.P. Verhaegh, 1992. Economic aspects of greenhouse horticulture, energy efficiency and $\mathrm{CO}_{2}$-emission in the Dutch glasshouse industry. Acta Hort., (ISHS) 312: 87.

33. Von Zabeltitz, C., 1992. Current state of technology and introduction to innovation in greenhouse horticulture. Acta Hort., (ISHS) 312: $19-28$. 